\title{
THE DAUGHTERS OF FIRE: WALTER HUGO KHOURI'S FEMALE GOTHIC
}

Daniel Serravalle de Sá

Universidade Federal de Santa Catarina

\begin{abstract}
This article seeks to investigate the connections between Walter Hugo Khouri's film As Filhas do Fogo (1978) and the Gothic stressing matters of gender, race and nationality. More than a simple re-classification, this Gothic framework of study seeks to demonstrate that the representation of necromancy, mysterious deaths and female imprisonment in a tropical manor suggest issues linked to Brazilian cultural identity and concerns. By associating Khouri's film to a form that is representative of popular entertainment this article seeks to establish a case in point of how the notion of Gothic can be a useful concept in the investigation of Brazilian film history.
\end{abstract}

Keywords: Brazilian cinema, lesbianism, nationhood, Female Gothic.

As Filhas do Fogo (1978), or the daughters of fire, is exemplary of the Gothic's transnational characteristics. The film portrays two young women whose stay at a colonial manor in the Brazilian countryside is

\begin{tabular}{|l|l|l|l|l|}
\hline Ilha do Desterro & Florianópolis & $n^{\circ} 62$ & p. 293- 318 & jan/jun 2012 \\
\hline
\end{tabular}


afflicted by paranormal events and mysterious deaths. In the course of the narrative, they become acquainted with a mysterious family friend, an elderly lady who claims to record the voices of the dead. Soon, the three female characters find themselves haunted by the ghost of one of the girls' mothers. Whilst the dividing line between this world and the next is obscured, family secrets are revealed and the situation escalates to a nightmarish finale. Ultimately, the luxuriant Brazilian forest envelops the entire house and the remnants of the eerie life and death spectacle that occurred there.

This article seeks to establish the notion of Gothic as a useful conceptual framework in the investigation of Brazilian films and culture in general by examining the historically specific underside of Brazil's largely optimistic surface. As Filhas do Fogo expresses anxieties about nation-, race-, and gender-related issues articulating the concerns of the 'unvoiced others' in the form of narrative and cinematographic elements. Khouri's treatment of these issues (and the gloomy, menacing features they receive) arguably represents a case in point of the Gothic in Brazil.

Filmmaker Walter Hugo Khouri is no stranger to the horror genre; his previous films Estranho Encontro (1958) and O Anjo da Noite (1974) are-alongside José Mojica Marins' Coffin Joe trilogyamong some the most significant Brazilian horror productions. However, the features that allow As Filhas do Fogo to be more precisely categorised as Gothic within the broad 'horror genre' deserve a more detailed explanation. The notion of what constitutes a 'Gothic film' is a thorny issue given that films that have been considered Gothic encompass "a brood of side genres, merging into a wider definition of the 'horror film' including monsters movies and slasher films, anything dealing with the supernatural or nightmarish fears" (Kaye 180). Although the Gothic is a well-established critical category in 
English Studies, to this day there is no consensus on a precise meaning of the term, and a singular definition of the Gothic has been difficult to isolate. Glennis Byron and David Punter state that the Gothic is "a set of irreconcilable and contradictory values both in aesthetic and political terms" (4). Lenora Ledwon argues that part of the difficulty lies in the fact that, 'rather than speaking of one monolithic category of "Gothic", it is more appropriate to recognise there are many Gothics' (261). And Fred Botting remarks that "the search for the Gothic [...] is a vain critical endeavour" (1). Despite these wellknown difficulties in arriving at one single definition of the Gothic, scholars have effectively delineated its contours and idiosyncrasies, identifying the Gothic in terms of conventions of characterisation, plot, tropes, topoi, discourses, modes of representation, and composites of all these aspects.

The Gothic status of As Filhas do Fogo derives precisely from the use of such particular tropes, settings, and iconography that make the Gothic a recognisable type of narrative. There are certain specific features and situations in the film that were popularised by eighteenth-century British Gothic narratives, namely, the isolated building in a foreign setting, vast and deserted countryside locations, and a focus on sexual and familial themes. Moreover, the Brazilian film departs from the explicit graphic violence typically found in horror films to offer a distinctive ethereal mood and harrowing atmosphere, "conflicts of aspiration and doom which are at the heart of the Gothic" (Punter 100). As Filhas do Fogo is an eerie ghost tale and, although stories about apparitions and spirits are by no means exclusive to the British Gothic but exist in the fiction and folklore of many nations, the languorous style and the air of doom that pervades the Brazilian film arguably place it among time-honoured Gothic films. Ultimately, the circumstances of Brazil's history and cultural 
institutions generate a series of significant inflections that determine a type of Gothic that both borrows and differs considerably from the Anglo-American versions.

\section{Walter Hugo Khouri in Brazilian cinema history}

Due to the concern with existentialism often noted in Khouri's films, the homogeneity of his oeuvre and distinctive personal marks, critics have traditionally tended to associate the director with filmmakers such as Bergman and Antonioni and therefore analysed his work in terms of "high" culture. An illuminating reading in this regard is Renato Luiz Pucci Jr.'s book O Equilibrio das Estrelas (2001), an admirable study on Khouri's connection with philosophy. However, this philosophical focus has not always worked to Khouri's benefit and it is not uncommon to come across critical statements affirming that his films are "too complicated"; or that his work is somewhat "alienated" since it was not in tune with the forms and social agenda of Cinema Novo and Teatro Arena-goals such as attacking the dictatorship politics, filming street movements and the Brazilian people, de-constructing sceneries and dramatic representation.

The key to understand this polarisation is to trace back to the critical aspirations for Brazilian national cinema that emerged in the 1950s developed by an influential generation of film critics and filmmakers. The framework of study they sought involved providing the country with a set of names, themes and films worthy of artistic and cultural appraisal (Viany 1959, Gonzaga and Gomes 1966). This project for the construction of a national cinema history resulted in rich theoretical and aesthetic debates, but it also created unnecessary restrictions on the scope of investigation. It purported an isolationist vision of the development process undergone by Brazilian cinema, 
ignoring historical appropriations from international cinema. The institutional discourse shaped by this project largely influenced the way cinema was studied and even produced in Brazil. In part, this explains why a number of academic publications on Brazilian cinema tend to focus their debate on art-house Cinema Novo production, in itself a sign of the national image film critics wish to project. An example of the influence of this critical endeavour can be seen in an important book on Brazilian cinema, published in the United States in 1982 and reissued in 1995, written by renowned Brazilianists and Brazilian academics and directors. The volume chooses to leave out both the "intellectualised" films of Walter Hugo Khouri and the "popular" films of José Mojica Marins to concentrate on the Cinema Novo productions as being emblematic of the country's cinema. More recently, a generation of researchers worked to fill the gaps in national cinema history (Ramos 1987, Bernardet 1995), and the creation of Socine (Sociedade Brasileira de Estudos de Cinema) has also contributed to this end.

Nine years after Khouri's death critical polarisation around his films still remain: on one hand, he is considered a master filmmaker of distinctive skill and sensibility that has captured São Paulo's cosmopolitan life focusing on timeless topics, akin to good literature and philosophy. On the other hand, he is accused of lacking an identifiable Brazilian identity and being an emulator of acclaimed European and Japanese directors, whose master-lines are allegedly inadequate in a country like Brazil, marked by a different historicalcultural development. Khouri's association with Vera Cruz-a film company from São Paulo which sought to produce films of international quality-has further contributed to certain specific theoretical claims that his work is the epitome of "foreignness" in Brazilian cinema. This reading of Khouri's As Filhas do Fogo intends 
to demonstrate the director's connections with the Gothic-a form that is representative of popular entertainment-and does so as a corrective to other critical works that have deemed his films either "profound" or too "complicated".

\section{Lesbians and unvoiced others: from domesticity to nationhood}

The situation experienced by three female characters in the film foregrounds issues of particular interest to discourses of gender, race, and nationhood. The assonance in their names (Ana, Diana, Mariana) suggests they can be seen as interrelated characters that represent different aspects of problems concerning the situation of the woman in society. More to the point, a society that condemns women' relationships with members of their own sex (Ana), motherhood and pregnancy as a problematic relationship with body (Diana), and a culture that determines women' entrapment in the domestic sphere (Mariana).

Set in an unnamed community in the countryside of Rio Grande do Sul, the southernmost state of Brazil, As Filhas do Fogo stands out from the majority of Khouri's production, usually set in the urban environment of São Paulo city. The particularity of the location is emphasised by means of scenes that focus on the frosty climate of southern Brazil, the predominantly European heritage of its inhabitants, and lines such as "your house looks like a little castle", in reference to the Germanic architecture brought by the immigrants that populated the region. This representation seeks to transmit the idea of a small and secluded society, a foreign hamlet in the remote areas of Brazil still linked with its ancestral origins and mysticism. If, on one hand, the choice of scenario stresses the 
absence of "tropical" elements, which are often identified as Brazilian national characteristics, on the other hand, it seeks to achieve the "transnational" effect that Khouri appreciated, i.e. a narrative that operates in several national contexts. In this particular sense, As Filhas do Fogo combines a versatile visual composition and remoteness of location that echoes films such as Lisa e il Diavolo (Mario Bava, 1974) and The Wicker Man (Robert Hardy, 1973).

Beyond the settings, this sense of oddity is established most effectively by character's perspective. ${ }^{1}$ Ana (Rosina Malbouisson), who is from São Paulo, finds the region peculiar. She introduces the story by means of voiceover narration and describes the location as "beautiful but not welcoming", persuading the spectator with her personal point of view. Ana is scared by local nature imagery such as dark ponds, mossy stones, and vegetation hanging from the trees. She is also frightened by the way the few local inhabitants look at her, and she feels that watchful eyes, which symbolically manifest themselves in different objects, are constantly observing her. This atmosphere of foreignness and the hostile environment perceived by the character serves to introduce a discourse of fear and apprehension that is typically found in Gothic narratives (Sage and Lloyd-Smith 14).

Ana travels to Rio Grande do Sul to visit her girlfriend Diana (Paola Morra), whom her family prohibited her to see after they found compromising correspondence between the two. Such prohibition speaks of the circumstances that express disapproval of women's sexual interaction with members of their own sex, and the issue of lesbianism appears in As Filhas do Fogo as an element that transgresses and disrupts the role conventionally assigned to women. Her family believe she is taking a seaside vacation on Florianópolis island, but she travels further south to see her lover. Ana is forced to lead a secret life in order to be able to express her sexuality because 
her family deem her desire unacceptable. In "Lesbian Gothic" Paulina Palmer states that

repressed desires and anxieties are, of course, of central importance to the lesbian subject who, lacking a history and a language to articulate her sexual orientation, may feel haunted by emotions which she cannot or dare not articulate. (119)

In this text Palmer explains how the Gothic is "an attractive choice of genre for writers involved in lesbian representation" (119) and demonstrates how the themes of secrecy, silence and "the unspeakable" are related to lesbian existence. According to the author something can be considered unspeakable "because the individual lacks knowledge of it, or because the knowledge is repressed, or because, though having access to it, the individual dare not admit the fact" (120). This sense of emotional and communicative impairment is expressed through the Gothic mode, that is, a discourse that emphasises the uncertainty, desperation and solitude of the human experience represented through characters trapped in a hostile environment. This seems to be precisely Ana's situation: she has been feeling a strange angst, not unlike a panic disorder, but she is unable to communicate it, and the vigilant eyes that she recognises in many objects act as harbingers of the events that are about to happen.

Once Ana arrives in her destiny, the narrative voice is handed over to Diana, who starts telling of her loving but remote relationship with the colonial manor that recalls the image of the dark, atmospheric, often ruined house found in so many Gothic novels (Sage xviii). Through Diana's narration viewers gain a new perspective on the story as they watch the girls take a sauna together and then stroll around the woods. The two girls love each other and they are also 
united by the complicated relationships they have with their families. Diana's father has been absent for the most part of her life and her mother passed away when she was a child. Soon viewers realise she has never quite managed to detach herself from the maternal figure, whose memory she keeps alive by recalling old stories and browsing through a family picture album. Diana's favourite picture is one of her mother in a long dress taken when she was pregnant with her.

Birth and death are thus embodied in the figure of the mother whose memory Diana reveres, and the matter of pregnancy is surrounded by the drama of guilt and flight surrounding childbirth, and its consequences. In "Female Gothic", Ellen Moers interprets Frankenstein (1818) as a metaphor for Mary Shelley's complicated relationship with childbirth, affirming that the subject of birth is the "most powerful, and most feminine" (81). In this influential feminist text Moers argues that the novel is the product of Shelley's many abortions and the premature death of her child. Since then, the idea of a "Female Gothic" has been associated with questions related to pregnancy and childbirth but also child loss, abortion, and fertility, as central issues of the female experience.

As Diana continues to indulge in her fixation on her mother's pregnancy, she starts to get in touch with her traumas. For example, she drastically complains about taking after her father's swarthy physical complexion, though everyone says she resembles her mother very much - not least in her sexual orientation, as will be revealed later in the film. She also laments having not grown up in that residence, and the viewers begin to regard Diana's caring but distant affection for the house as symbolic of the issue of pregnancy and her bond with her own mother. Diana's connection with reality gets hazier and hazier as she starts talking about the dead people in her family as if they were alive. The only person who perceives Diana as tormented and obsessed 
is the maid Mariana (Maria Rosa). The housekeeper warns Ana about Diana's strange behaviour, but it is too late for them and doom is inevitable in this tale of hereditary family madness in the wilderness.

Mariana is a mixed-race woman of apparent Afro-Amerindian origins, and she functions in the film as the "local colour" in that all-European realm. She works as a head-servant of the manor, but she often acts beyond her duties of house carer, speaking to Diana like a big sister. Although there are no explicit scenes of sexuality involving the three girls, while the maid is serving breakfast, Diana suggestively says to Ana that "Mariana has got incredible hands", and they all share a laugh. But whilst Diana shows contempt for the other sex, declaring that "all men are vagabonds", Mariana makes love to a rambler who seeks the house for food and work, with disastrous consequences that will cause his death. Mariana's specific situation speaks of female oppression in a culture that determines women's confinement in the domestic sphere. In one of her lines she declares having been born in the region, having never left it and seldom been away from the house. Mariana appears to be conformed to her situation, and perhaps for that reason she seems the least disturbed of the three. These socially sanctioned confinements have a longstanding history of representation in Gothic fiction, the "damsel in distress" locked in the tower being a prime example. The Gothic emerges here in the figure of the woman trapped within the domestic space and in the trope of the "house" as a private female domain, generally portrayed as an ominous location, in which dreams of freedom are destined to fail.

As well as stressing the centrality of the female body, feminist criticism also favoured the household as a stereotypical space to discuss the issue of power. Traditionally, these critics regarded the home as a domestic prison of damsels in distress who struggled 
against oppressive patriarchal forces. However, such interpretation of women's private and quotidian experience was only early days for the feminist project. A later generation of feminist critics attacked such clear-cut divisions that separate public and private spheres because they end up reproducing binary gender hierarchies (public/male and domestic/female). More recently, critics such as Victoria Kuttainen have demonstrated how femalecentred, domestic narratives can be read in terms of nationhood or "nationalist articulations in which the domestic sphere signals not merely a female domain, but also a figure of domestic nationspace" (3). Kuttainen presents a complex articulation between the domestic sphere and nationhood, arguing that in the profusion of everyday details (designed to produce a semblance of authenticity, verisimilitude and "realism") the reader can engage in metonymic readings, which take the stress off the larger structures in which the lives of characters are caught. This interpretation relies on the viewer's capacity to see beyond straightforward representations and detect the collective in the work of art.

But how exactly can homely stories set in small towns be figurative of the political, civic space, and national spheres? According to Kuttainen the way out of this potential paradox is to look for implicit concerns about nationhood in these stories, as they often appear in the form of concealed reactions to dominant figurations; they rely upon many of the same tropes and characterisations that enable any other story to be read as a "state-of-the-nation" narrative. Kuttainen defends that some female-centred narratives are "conflated with an organic kind of birthing process in which stories simply emerge out of other stories, without an overarching master-plan" (7). The idea here is that by means of narrative fragmentation a text elicits numerous interpretations that are also encoded within the larger 
text. Instead of one single interpretation, a narrative would open up to reveal a multiplicity of stories that develop out of each other like offspring of a fertile, reproductive mother-narrative. Moreover, Ismail Xavier discusses some characteristics of historical allegory in film explaining why it has been a privileged mode of interpretation at particular historical moments (346). Such connections are often created through the use of an individual (a character) who stands for a larger social class or political group. ${ }^{2}$ Recognising a national dimension in a female, domestic narrative requires the ability to perceive homologies, and recognising national allegories in such narratives requires the understanding of private lives as representative of public destinies.

The point here is that Khouri's film may also be read in terms of nationhood. In the Brazilian context, and especially because of the casting of a black actress for the role of domestic female, this type of social imprisonment arguably suggests the psychological legacy of slavery, which lingers and is an integral part of Brazilian identity. The issue of her ethnicity, which had previously appeared in Diana's dissatisfaction with her dark looks, gains a different dimension in relation to this character, particularly because Mariana is "freed" in the end. But the issue of imprisonment also suggests a historical link with the military dictatorship as an oppressive institution that was active in that specific time period. In the end, Mariana is the only character that manages to escape the manor; once Ana and Diana are dead, it is through her perspective that viewers continue to follow the narrative. It is a frosty daybreak and through Mariana's eyes the viewers observe the impenetrable vegetation that has overwhelmed the entire house. The transition period represented by the indistinct light of dawn and the fact that she is now carrying the rambler's rucksack are indications she has freed herself from the "castle" and 
perhaps become the rambler. In spite of this open-ended finale, the situation of domestic confinement experienced by Mariana is not in itself any less potent because it is amended before the end of the film.

There are at least two possible ways to understand this finale, and the distinct interpretations oscillate between conservative ideological function and radical potential. The first one suggests that Ana and Diana, who do not escape the "castle", remain the tragic victims of a male-centred culture and that Mariana survives only because she has heterosexual intercourse. Although this interpretation points to a familiar conservative ending, the film allows for a variety of understandings, all symbolic but not all of them misogynist. The second interpretation points to the possibilities of resonance between the Gothic tradition and Brazilian history, articulating a coded understanding of the darker underside of the nation. The fact that the natural Brazilian environment ultimately overwhelms the colonial manor can be considered a metonym for a backlash on an oppressive institution that symbolises the installed dictatorship. In the book Horror: The Aurum Film Encyclopaedia (1985), Phil Hardy favours this particular interpretation of As Filhas do Fogo regarding the incorporation of the manor by the forest "as if Brazil itself had re-asserted its enduring construction of its history" (328). The psychic division of the frightened, obsessed, and oppressed self-an association suggested by the names Ana, Diana and Mariana-no doubt represents the articulations of concerns of unvoiced females, on account of the intolerance they encounter, in a predominately male culture. But it also represents the concerns of several unvoiced others in a broader national context linked to the horrors of slavery and the dread of dictatorship. In all these cases the Gothic form persistently emerges as the most appropriate mode for dealing with 
controlling institutions, mechanisms of alienation and destruction, as seems to be the case here in Khouri's As Filhas do Fogo.

\section{Zombies, drunkards and fathers' ghosts: ineffectual male characters}

The male characters in As Filhas do Fogo are mostly nameless; they are recurrently referred to as the gardener, the grandfather or the rambler. The circumstances reflect the peripheral condition of male characters in this female-centred narrative but this does not mean they are inconsequential to the story. The male characters are represented in three different ways. The first set appearing physically in the film but being secondary to the narrative, as exemplified by the speechless butler (Helmut Hosse) in Dagmar's castle-like house and the gardener (Rudolf Machalowski) in Diana's property, who only speaks as much as it is necessary to contribute to the scene. The role of these minor characters in the film is primarily to help produce dissonance and anticipation; they labour on the audiences' expectations and perhaps assist the viewers achieving catharsis. Their blank gazes, resounding silences and zombie-like behaviour generate tension in the narrative, supporting and accentuating the protagonist's part.

The second group if formed by male characters in absentia, namely Diana's father and grandfather, who do not appear onscreen but whose presence is constantly being alluded to. Although they are just ghosts from the past, these characters have an important function in the narrative, which is establishing parallels between the generations. It seems that Diana's aforementioned problematic father/daughter relationship mirrors that between her own mother and grandfather. This interpretation is better observed in Diana's 
flashbacks, wherein the viewer is transported to a time when she was a child and witnessed familial divergences.

Troubled father/daughter relationships and how they echo across the generations are the focal point of these digressive scenes. Both male figures seem to have been distant, but while Diana holds her father in contempt, she admires her grandfather, a German migrant who came to Brazil after WWI and built the colonial manor in the wilderness after slashing and burning the native vegetation-hence the name the daughters of fire. He then re-planted the trees with seeds brought from Germany, perhaps in an attempt to re-create the natural world he was familiar with in his homeland. He delimited his land with a fence to prevent trespassing both by people and by the dense Brazilian forest that surrounds the property-a protective measure that also leaves the house dwellers marooned. Diana identifies with her grandfather's wish for isolation and appreciates the way he tried to recreate his "motherland" (as the expression is used in Portuguese). Similarly, Diana seeks the house to reminisce about her mother, and because it provides the perfect retreat to be in isolation with her lover. Diana's grandfather was also an enthusiast of war memorabilia and possessed a pistol that her father inherited and occasionally used to shoot the trees (scenes of red sap pouring from trees trunks are recurrent in the film). Although they are not physically present, these two spectral figures are powerful forces in the plot, figuring prominently in the minds of characters and audience.

The balance of the household, in which male presence is reduced to zombie-like servants and fathers' ghosts, is disturbed by the arrival of a nameless rambler (Serafim Gonzales) who seeks the manor for shelter. He is representative of the third set of male characters. The rambler is charming, well spoken, and claims to be wealthy. Still he chooses to wander without destination because it is a worry-free lifestyle. In 
certain ways this character can be seen as the archetype of the roving wanderer: poor and dignified, hungry but free. His worldliness can be seen as the opposite of Mariana's domesticity and, in this sense, they are each other's mirrors. Diana is touched by the rambler's words and allows him in the house to have food and wine. But soon the rambler shows he is a chronic drinker and a lustful man. He seduces Mariana and infiltrates the house at night in search of more alcohol. The two girls catch him in the wine cellar and Diana points her pistol at him. He talks his way out of the situation and even convinces her to give him more wine. But in an inapt move he suggests sex and Diana dislikes his attitude; in a previously hidden streak of sadism, she orders him to drink from the barrel. He accepts the humiliation and indulges in the wine. After that, he reveals Diana's pistol is too old to shoot and that he had known it from the start-indeed the pistol does not work on him. Still, the girls manage to expel the rambler from the house and, next morning, he is (fittingly) found drowned in a lake, parodically reworking Ophelia's destiny.

Many films by Khouri have a bon vivant character named Marcelo, whom many critics consider to be a projection of Khouri's persona (Ramos and Miranda 311). Ranieri Brandão (par. 5) suggests that the rambler is a tragic and poetic facet of Marcelo. This may be so, but the rambler is also a pathetic figure, ruined by addiction and excess. The rambler will re-appear again in the form of a masked stranger whom the girls stumble across on their way to a masquerade. In a remarkably unsettling moment, he offers Ana and Diana wine. After that episode, the material world starts getting seriously undercut by hallucinations and apparitions from the spirit world. Soon both worlds become intertwined and the realm of the dead invades and takes over.

The male characters in As Filhas do Fogo can be seen as ineffective individuals: the servants are devoid of will power, the 
fathers are incapable of defending their daughters (symbolically represented by the pistol), while the rambler is morally twisted and self-defeated by compulsive binge drinking. They seem unable to project power, aggression or transgressive desires, which makes them strong candidates for entering a Female Gothic world wherein gender differences are reversed. By inverting the usual male/female assumptions based on patriarchal authority, the film critiques and exposes these relationships by means of "role-reversing" exercises. But the fact that the male characters are either dismissed or dead even before the film reaches its climax suggests, perhaps, that they serve more to highlight social and sexual repression than to demonstrate any possibility of legitimate redress or reform.

\section{Refusing to become the mother}

Wandering around the Brazilian forest the two girls meet Dagmar (Karin Rodrigues), an old friend of Diana's mother who appears to be registering the sounds of birds in the forest. Later Dagmar will reveal that she is in fact conducing experiments in parapsychology, recording the voices of the dead. Dagmar can be seen as the figure of the witch belonging to "a feminine culture rooted in the natural world" (Ringel 256) but, in a modern-day twist, her communication with the world beyond is done via microphones and tape recorders. The presence of these technological devices suggests she can also be associated with another archetypical character linked to Prometheus and which echoes characters from the Gothic tradition such as Victor Frankenstein, Mr. Jekyll, and other "mad scientist" types. Dagmar seems to be engaged in a Faustian search for knowledge, seeking power derived from technology and satanic bargains involving souls. 
This potential double interpretation of Dagmar corroborates the multiplicity of the role of women in the film.

A particularly disturbing moment in the film is the scene in which Dagmar reveals that the spirit world is a place of sorrow and bitterness. The necromancer explains that the voices she records only transmit angst and despair, for loneliness and fear represent mankind's tragic destiny even after death. Dagmar has been communicating with Diana's mother for over ten years. According to her paranormal investigations much of the same torment felt in this life continues in the next and, to make matters worse, there are none of the bodily pleasures to relieve the weight of existence.

The two girls are invited to visit Dagmar's house, where her aunt Gertrude (Maria Hussemann) offers to make them a dress for the seasonal masquerade that is about to happen. In her house, the ghost of the mother Sílvia (Selma Egrei) appears for the first time between Diana and a mirror as Diana is trying on a dress. Mother and daughter are united at last in the mirror reflection, but only Dagmar seems to be able to see it. Here supporting actress Selma Egrei delivers a most impressive, scene-stealing role playing the strange mother that never utters a word and just stands staring-here again the problem of the unvoiced. Whenever Silvia's ghost appears her strange and bewitching gaze dominates the scene. Gloom and melancholy are added by Rogério Duprat's soundtrack, and the combination is certain to send chills down the spine.

The mirror scene is another watershed moment in the film, marking the beginning of time/space alternations. The mirror bridges past and present, this world and the next, for-as revealed later-the dressmaker Gertrude has been dead for many years. Ana also starts hearing and then seeing Sílvia’s ghost, which only adds to her fear of the beckoning surroundings controlling her every move. 
The whole situation becomes an unbearable and excessive emotional experience for her. Ana dies of this mysterious spiritual malaise, and it seems that Dagmar was her tormentor or at least partially responsible for her terror. Diana also becomes conscious of these time/space alternations upon having a vision in which she finds out Dagmar and Silvia were more than just friends. Lesbianism emerges here as a generational parallel between mother and daughter, another example of the many mirror-like relations in this film.

The film climaxes in Dagmar's house, when Diana finally sees her pregnant mother wearing the very same dress shown in the photograph. Silvia walks towards her daughter staring intensely. But instead of being glad or thankful with this encounter she seems to have longed for, Diana is frightened. Dagmar is also moving towards Diana, but her presence is perceived as overwhelming and menacing. Diana shoots Dagmar with her grandfather's pistol—which eerily works on her. Terrified, the girl tries to escape the manor but finds doors and windows blocked by overgrown vegetation. The house has been totally enveloped in forest foliage, symbolising both a return to Nature and to her mother's womb.

Why Diana shoots Dagmar remains a mystery: was she jealous of her mother's lover? Or, with Ana and Sílvia both dead, was she reacting to what she considered a sexual advance from Dagmar? Whatever the interpretation, it seems clear that the girl refuses to re-enact her mother's role, and this results in a dead end for her. This surreal finale can be considered a non-rational solution to a situation that oscillates from an Oedipal situation of rivalry to circumstances linked to self-annihilation and death-drives. Diana does not escape the pre-Oedipal mother, from whom she must separate in order to become a desiring subject, nor does she escape the Oedipal father, who in incest imprisons the daughter resulting in her defeat and 
312 Daniel Serravalle de Sá, The Daughters of Fire: ...

death. In Juliann E. Fleenor's Female Gothic (1983) the entrapped female is analysed as an articulation of the passage from girlhood to female maturity and socialisations in which the Gothic enactor escapes from the all-embracing mother into individualisation through sexual response (the girl's difficulty in separating from the mother when she does not have the obvious marker of sexual difference from her that the son possesses). In the essay "The Gothic Mirror" Claire Kahane sees "the spectral presence of the dead-undead mother, archaic and all-encompassing, [as] a ghost signifying the problematics of femininity which the heroine must confront" (336).

There is no straightforward conclusion for As Filhas do Fogo; this surreal narrative expands itself towards multiple levels of interpretation, creating different layers of meaning without a definite conclusion. More typically, critical issues on Female Gothic are read psychoanalytically; however, another possible symbolic interpretation may argue that the same situation refers to female nightmares of oppression and enclosure in a way that allows radical social protest. The "house as a prison" problematises the allegedly safety of the domestic sphere while also dramatising the social relations of a male-dominated society. At one point it seemed possible for the lesbian characters to establish an independent community, psychologically and geographically unimpeded by male control. But Dagmar disrupts this possibility as an agent of the deaths of the potential members of this community. Diana's mental conflicts undermine this possibility, as her ambiguous sense of individual liberation seems to encompass aspects of the self that she feels anxious or guilty about. In this particular sense the Gothic form is to be particularly useful in calling attention to matters related to a female autonomous self. The appropriation of the Female Gothic 
by a male filmmaker such as Khouri may be seem a critique of the ideology of separate spheres, the heroines' refusal or allegiance to the house being assertive of the history-bound patriarchy that the institution ultimately articulates.

\section{Conclusion}

As Filhas do Fogo is Walter Hugo Khouri's seventeenth film; it was produced at a time when Brazilian society was evidently receptive to the concept of psychic and occult phenomena. The feats of selfproclaimed psychic Uri Geller were often shown on Brazilian TV programmes, Aleister Crowley was turned into a cultural icon in the hands of musicians such as Raul Seixas and Paulo Coelho, and the Spanish-born padre Quevedo, a Catholic challenger of paranormal claims and pseudoscience, was a regular figure in Brazilian media. As Filhas do Fogo is also part of a more general worldwide trend or interest around issues of paranormality in films released in the seventies, which can be verified in productions such as Necrophagus (Miguel Madrid, 1971), Tutti i Colori del Buio (Sergio Martino, 1972), Burnt Offerings (Dan Curtis, 1976), Carrie (Brian de Palma, 1976), Audrey Rose (Robert Wise, 1977) and many others.

Khouri was no supporter of the lesbian cause, but he arguably put the lesbian subject in the centre of this film in connection with a number of Gothic tropes and conventions. This article began by arguing that Walter Hugo Khouri is an important filmmaker, whose work should be studied in order to understand a certain specific part of Brazilian film history. However, rather than the more traditional ways in which his films have been read, this paper suggests a framework of study which can potentially link As Filhas do Fogo to other popular international productions. 
314 Daniel Serravalle de Sá, The Daughters of Fire: ...

The focus on representations of female homosexuality, issues of domesticity, and race brings into light a discussion that stresses a broader situation of the "unvoiced other". This part of the analysis concentrates, more particularly, on how the combination of the power related matters, domestic narratives and the Gothic may work in terms of historiographic metafiction. The articulation between the domestic sphere and nationhood was specifically argued in relation to Mariana's domestic situation and cultural identity. This metonymic reading takes the stress off the larger structures in which the lives of characters are caught to suggest issues of nationhood (slavery and dictatorship) as a way to frame Brazilian history of hardship enacted in Brazilian Nature.

I also discuss male characters in the film in terms of absence and ineffectuality. Although they are important for the development of the narrative, these characters are devoid of will and desire. In this sense, they resemble the feeble male heroes of eighteenth-century Gothic novels, who are often incapable of defending themselves and the heroine. The idea of blurred gender roles was used to explain their incapacity to project power, which makes them meaningful characters in a film concerned with a Female Gothic world.

The next section concentrates in Diana's refusal to re-enact her mother's role, but invariably repeating her destiny of loss and death. The non-rational finale leaves the film open to interpretations that include Diana's impossible task of separating herself from the mother's role (individualisation) and circumstances of domestic imprisonment, which dramatises the social relations of a maledominated society. Both these readings are based on symbolic interpretations linked to female nightmares of oppression and enclosure in a way that allows radical social protest.

Finally, reinforcing Guido Bilharinho's observations (31), it must be mentioned that Khouri's films are extremely hard to find. 
And although Cinemagia released an important three-DVD box set in 2003, it hardly covers his oeuvre of twenty-six films. As Filhas do Fogo did not make this box and, as far as I know, it was not released for home entertainment in Brazil, making it an extremely rare film to find. The copy I watched was bootlegged from a Torrent site, which in turn was ripped from an old television broadcast by TV Bandeirantes (the company's logo can be seen). All in all, this article has sought to establish the Gothic as the most appropriate mode for dealing with the Brazilian experience of the monstrous images that a homophobic, allcontrolling culture assigns to the female subject and how mechanisms of alienation and destruction operate within this society.

\section{Notes}

1. The division of Gothic fiction into male and female traditions is customary and usually follows the gender of the author (Milbank 54). Nonetheless, such gender division is not consistent, for example, Clara Reeve, Charlotte Dacré and Mary Shelly use point of view to write in the 'male' tradition; while J. Sheridan Le Fanu and Charles Maturin write in the 'female. Khouri's film is an example of a male author using point of view to focus on the centrality of female characters.

2. Xavier goes on to argue that allegorical expression is especially prevalent in times of political repression and serves as a means of offering 'disguised comment on the present' (354). In 1976 Brazil was under a military dictatorship that imprisoned, tortured and killed Brazilians such as journalist Vladmir Herzog and factory worker Manuel Fiel Filho.

\section{References}

As Filhas do Fogo, Brazil. Editora Três/Lynx Filmes. dir. Walter Hugo Khouri, 1978. Film.

Bernardet, Jean-Claude. Cinema Brasileiro: propostas para uma história. Rio de Janeiro: Paz e Terra, 1979. 
Bernardet, Jean-Claude. Historiografia Clássica do Cinema Brasileiro. São Paulo: Annablume, 1995.

Bilharinho, Guido. O Cinema Brasileiro nos anos 50 e 60. Uberaba: ITC, 2009.

Botting, Fred, ed. The Gothic. London: D.S. Brewer, 2001.

Brandão, Ranieri. "As Filhas do Fogo (1978, Walter Hugo Khouri)". Filmologia \#2. 17 December 2011 <http://www.filmologia.com. br/?page_id=1724>

Byron, Glennis, and David Punter. The Gothic. London: Blackwell, 2004.

Fleenor, Juliann E., ed. Female Gothic. Montreal: Eden Press, 1983.

Fletcher, John. "Primal Scenes and the Female Gothic: Rebecca and Gaslight.” Screen, 36.4 (1995): 341-370.

Gomes, PauloEmílioSalles. "Cinema:atrajectorywithinunderdevelopment.” Brazilian Cinema. Ed. R. Johnson and R. Stam. Columbia: Columbia University Press, 1995. 244-256.

Gonzaga, Adhemar, and Paulo Emílio Salles Gomes. Setenta anos de cinema brasileiro. Rio de Janeiro: Editora Expressão e Cultura, 1966.

Hansen, João Adolfo. Alegoria: Construção e Interpretação da Metáfora. Campinas: Hedra, 2006.

Hardy, Phil. "As Filhas do Fogo aka Daughters of Fire.” Horror (Aurum Film Encyclopaedia). London: Aurum Press, 1985. 328.

Johnson, Randall, and Robert Stam, eds. Brazilian Cinema. Austin: University of Texas Press, 1988.

Kahane, Claire. 'The Gothic Mirror.' The (M)other Tongue: Essays in Feminist Psychoanalytic Interpretation. Ed. Shirley Nelson Garner, Claire Kahane, and Madelon Sprengnether. Ithaca: Cornell University Press, 1985. 334351.

Kaye, Heidi. "Gothic film." A Companion to the Gothic. Ed. David Punter. Oxford: Blackwell Publishing, 2001. 180-192.

Kuttainen, Victoria. "Sweet Traps: Feminist Fantasies of Domestic Confinement on the Cusp of Postcolonial Australia." Australian Studies, 1 (1) 2009. 1-26. 
Lewdon, Lenora. “Twin Peaks and the Television Gothic." Literature/Film Quarterly, 21.4 (1993): 217-220.

Martinelli, Sérgio et al. Vera Cruz: imagens e história do Cinema Brasileiro. São Paulo: Abooks, 2005.

Milbank, Allison. 'Female Gothic'. The Handbook to Gothic Literature. Ed. Marie Mulvey-Roberts. New York: New York University Press, 1998. 5357.

Moers, Ellen. "Female Gothic." The Endurance of Frankenstein: Essays on Mary Shelley's Novel. Ed. George Levine and U.C. Knoeflmacher. Berkeley: University of California Press, 1979. 77-87.

Palmer, Paulina. "Lesbian Gothic: Genre, Transformation, Transgression.” Gothic Studies: The Female Gothic, 6.1 (2004): 118-130.

Pucci Jr, Renato Luiz. O Equilíbrio das Estrelas: filosofia e imagens no cinema de Walter Hugo Khouri. São Paulo: Annablumme, 2001.

Punter, David. The Literature of Terror: a History of Gothic Fictions from 1765 to the Present Day. London: Longman, 1996.

Ramos, Fernão (org). História do Cinema Brasileiro. São Paulo: Art Editora, 1987.

Ramos, Fernão and Luiz Felipe Miranda (orgs). A Enciclopédia do Cinema Brasileiro. São Paulo: Senac, 1997.

Revista Zingu! Cinema Brasileiro, Edição \# 49. 18 Dezembro $2011<$ http:// www.revistazingu.net/edicao-49>

Ringel, Faye. "Witches and Witchcraft". The Handbook to Gothic Literature. Marie Mulvey-Roberts ed. New York: New York University Press, 1998.

Sage, Victor. Horror Fiction in the Protestant Tradition. London: Palgrave Macmillan, 1998.

Sage, Victor and Allan Lloyd-Smith, eds. Modern Gothic, a Reader. Manchester: Manchester University Press, 1996.

Serravalle de Sá, Daniel. Tropical Gothic. Rome: Aracne , 2010.

Viany, Alex. Introdução ao Cinema Brasileiro. Rio de Janeiro: Instituto Nacional do Livro, 1959. 
318 Daniel Serravalle de Sá, The Daughters of Fire: ...

Xavier, Ismail. "Historical allegory"' A Companion to Film Theory. Ed. T. Miller and R. Stam. Malden: Blackwell Publishers, 1986. 333-362.

[Received in 15/11/2011. Approved in 11/04/2012] 